\title{
AN INNOVATIVE EDUCATIONAL ENVIRONMENT FOR FORMING PROFESSIONAL COMPETENCY IN FUTURE SKILLED WORKERS
}

\author{
Tetiana Piatnychuk, \\ $\mathrm{PhD}$ in Pedagogy, Deputy Head of Department for Research, Educational and Methodical Support of Vocational Education \\ Content at the Institute for Modernization of Education Content, \\ http://orcid.org/0000-0002-5607-2949 \\ e-mail: ptv2613@ukr.net
}

\begin{abstract}
The article analyzes the essence of such a concept as "an innovative educational environment" and defines its content for vocational education institutions. It illustrates the work experience of teaching staff in educational institutions in creating an innovative educational environment and forming professional competency in future workers. It also describes the main approaches to creating an innovative educational environment in vocational education institutions for vocational training of future skilled workers. They include humanistic approaches (anthropocentrism, relationship harmony, forming intellectual culture); systemic approaches (improving an educational environment as a holistic developing system); informational approaches (a sufficient level of information culture); innovative approaches (creative interaction, forming readiness for future professional activity).

Based on the practical experience of vocational education institutions in Ukraine, pedagogical conditions for creating and maintaining an informational educational environment in educational institutions were singled out: partnership cooperation, respect and trust of all participants in the educational process; focus on development and self-development of every individual; creative activity; an effective use of scientific and methodological, material and technical capabilities and human resources of educational institutions; employment of personalityoriented innovative pedagogical technologies.

The emphasis is placed on the importance of implementing personality-oriented pedagogical technologies in the educational process. It is shown that vocational education teachers have different views on the approaches to creating an innovative educational environment. However, it is agreed that the process of creating an innovative educational environment significantly influences the processes of forming and developing professional skills in teachers, strengthening professional relations between them, facilitating pedagogical innovations.
\end{abstract}

Keywords: innovative educational environment, professional competency, readiness of educators for innovation, experimental work.

Introduction. The modern labour market requires that workers should be professionally competent, willing to continuously improve their professional results and personal qualities. The market economy highlights the need for qualified workers, who are competitive in the labour market and meet the modern requirements of employers. The modern system of vocational education in Ukraine should take into account globalization processes in society, constant changes in technology, the importance of effective interaction between education and the labour market, changes in the social life of the country and the need for continuing vocational education. It should contribute to regular update on educational content and vocational training of skilled competitive workers in accordance with the requirements of the national and regional labour markets. These objectives, in turn, require that the organization of work in vocational education institutions should be changed: it is essential to introduce new pedagogical ideas, pedagogical technologies, forms and methods of education, work organization and institution management. According to N. Nychkalo (2008, p. 176), "the innovative activity generates new models, pedagogical projects and 
pedagogical technologies aimed at improving the quality of the educational process and all educational work".

Therefore, it is vital to create an innovative educational environment and use innovative pedagogical technologies to form professional competency in future workers in vocational education institutions.

Materials and methods. Innovative educational processes were studied by I. Bekh, N. Bibik, L. Danylenko, D. Puzikova, H. Shchekatunova and L. Vashchenko. The capacities of the educational environment in developing personality were investigated by N. Hontarovska, O. Humeniuk, A. Katushov, N. Krylova, K. Prykhodchenko, V. Stepanov et al. Some issues of forming educational environment were analyzed by L. Buiev, Yu. Manuilova, L. Novikov, V. Petrovskyi, N. Selivanova, I. Yakymanska, V. Yasvin et al. Such scholars as E. Bachynska, I. Frumin, S. Hershunskyi, V. Hynetsynskyi, B. Sierikov and B. Yelkonin explored the problems of creating an educational environment.

However, the existing findings do not sufficiently justify the aspects of forming professional competency in future workers within an innovative educational environment in vocational education institutions.

Research methods include theoretical methods (an analysis of scientific works by Ukrainian and foreign authors, legal documents, educational and methodical sources, educational activity of students and teachers, comparison, systematization and generalization of theoretical and experimental data); empirical methods (observation, modelling of educational situations, interviews, surveys, expert assessment, pedagogical experiment with quantitative and qualitative analysis of results); statistical methods (statistical criteria for verifying the significance of differences, computer tools for statistical processing of experimental data).

The research aims to reveal the essence of such a concept as "an innovative educational environment" in vocational education institutions, to determine its role in forming professional competency in future workers, analyze the experience of educational institutions in creating an innovative educational environment.

Results and discussions. Education is the most important factor in developing modern society since its content, quality and improvement contribute to solving thorny issues of humanity.

The Law of Ukraine "On Education" defines the following goals of vocational education: to form and develop professional competencies required for professional activity in a particular field and ensure the competitiveness of workers in the labour market, as well as their mobility and prospects of career growth throughout life (Zakonodavstvo Ukrainy, 2017).
Nowadays, the process of forming professional competency in a worker as a creative personality is possible only in an innovative educational environment. Innovative focus of pedagogical activity in vocational education institutions under modern conditions is caused by the need to update the content and organization of the educational process. In this context, the role of vocational education teachers, who provide vocational training for future skills workers, is growing significantly. Indeed, an innovative educational environment is a means of revealing their potential and forming professional competency, updating the content of education, creating and improving conditions for development, selfdevelopment and realization of creative powers.

The process of forming an innovative educational environment in vocational education institutions with the aim to provide vocational training of future skilled workers is based on such approaches as:

$\checkmark \quad$ humanistic approaches - they reflect anthropocentric principles of developing the modern society, ensuring relations harmony, forming an intellectual culture in future workers;

systemic approaches - they are aimed at improving the educational process in vocational education institutions, establishing the links between its components and defining the educational environment as a coherent system, which ensures the development of future workers;

$\checkmark \quad$ informational approaches - they ensure a sufficient level of information culture in future workers in the use of modern computer technologies and effectively form their professional competency;

$\checkmark$ innovative approaches - they promote creative interaction between the participants in the educational process and contribute to forming students' readiness for future professional activities.

Today, the society urges Ukrainian education to reconsider the very idea of education, coordinate its strategies with the innovative culture of teaching activity and create a new quality of an innovative environment (Vashchenko, 2012, p. 37).

The current research considers a concept of "an innovative educational environment" to identify the patterns of its influence on the development of professional competency. The analysis of the scientific literature shows that the educational environment as a set of values and examples of successfully solved life goals is a source for developing a personality. A. Katushov (2001) regards the concept of "an innovative educational environment" as a combination of intellectual and material conditions in an educational institution, which ensures self-development of a free and active personality and helps to realize the creative potential of students. He believes that an educational environment is a functional and spatial association of 
all participants in the educational process between whom close and diverse relations are established; it is seen as a model of sociocultural space, where a personality is developed. N. Razina (2009) understands a concept of "an innovative educational environment" as a complex of interconnected conditions, which promote education, innovative and creative thinking and professionalism. O. Shapran (2010) defines an innovative educational environment as a wellorganized pedagogical space of life activity, which contributes to developing an innovative resource of a personality; as an integrated means of accumulating and realizing the innovative potential of an educational institution. L. Vashchenko (2012, p. 39) indicates that an innovative environment incorporating innovative content and forms of the organization provides conditions for forming a new quality of professional, scientific, pedagogical and managerial activity and thus creates a powerful potential resource for developing the professional activity.

It must be noted that personality-oriented pedagogical technologies play an important role in the process of acquiring professional competency. H. Romanova (2014, p. 5) defines the following most significant features of these technologies: the priority of learners' personal and meaningful sphere, in particular motivation and values; the reorientation of the educational process towards formulating and solving educational (cognitive, research, project) tasks; the shift in the teacher's role - from an informant and controller to a coordinator and facilitator, who contributes to creating the conditions for selfdevelopment of students.

H. Shchekatunova (2013) understands "an innovative educational environment" as a system of influences and conditions for cultivating a personality based on a given model, as well as the opportunities for self-development in the social and thematic environment.

A. Kukh (2008) defines the following interconnected components of educational environment: participants, resources, facilities, ideas and technologies. He states that the participants and resources component identifies the participants in an educational environment and determines the conditions for implementing their subject-subject interaction; the facilities component provides an educational environment with relevant equipment; the ideas and technologies component singles out normative techniques and technologies to achieve the expected learning outcomes (Kukh, 2012, p. 74).

It is necessary to make the following steps so that the educational environment of vocational education institutions can be regarded as innovative:

$\checkmark$ to create and improve facilities in accordance with the requirements of the labour market and standards relying on competency-based approach; $\checkmark$ to introduce information and communication technologies in the educational process;

$\checkmark \quad$ to create relevant pedagogical conditions for forming professional competency in accordance with the standard requirements of vocational education.

It must be noted that modern Ukrainian teachers of vocational education clearly understand the need to create an effective educational environment with the aim to form professional competency in future skilled workers. Every vocational education institution has its own special material and technical potential to create an innovative educational environment. Therefore, considerable attention is paid to the process of creating an informational educational environment and introducing the latest information technologies in vocational education.

In the framework of the All-Ukrainian experiment between 2014 and 2017 (the Order of the Ministry of Education and Science of Ukraine No 424 dated April 9, 2015), Odesa Higher Vocational School of Trade and Food Technologies established a mobile, dynamic and open structure of an informational and educational environment. It covers the following modules: a content library; a database of teaching materials; a reference and search engine; e-resources on general, socioeconomic and management courses; a depositary; electronic encyclopedias and reference books; a repository; an educational kit for designing personal informational and educational environment for teachers; a system of distance learning; other scientifically, methodically and didactically justified modules. The results obtained from the experiment show that the level of motivation, values and cognitive aspects of students' professional competency has increased significantly (up to $15 \%$ ).

In the framework of the exhibitions, titled "Innovation in Modern Education" and "Modern Educational Institutions", vocational education institutions from different regions of Ukraine have submitted more than 150 works to be considered for the nomination "Innovative Educational Environment: New Challenges and Modern Solutions".

In 2018, Zhmerynka Higher Vocational School studied the experience in creating an innovative educational environment for vocational training of such workers as a train conductor, a ticket controller and an acceptance/delivery agent. This activity was mainly aimed at updating the organization of the educational process and education content; forming information and communication competency in students and teaching staff; improving professional competency of teaching staff due to mastering innovative teaching technologies and research activities. This involves the following practical activities: holding workshops, psychological and pedagogical seminars on innovative pedagogical technologies; creating personal websites, 
using Prezzi.com. for interactive online presentations. The institution introduces profession-oriented educational and controlling computer programmes, modern methods and personal developing technologies to achieve the expected outcomes. All these measures make it possible to increase the level of professional competency up to $10-15 \%$.

In Kyiv Higher Vocational School No 33, the main objectives of teaching staff are the following: to prepare successful workers, who are able to learn throughout life, set goals and achieve them, think critically, work in teams, interact with others and apply different professional skills. To fulfill these objectives, the teaching staff agreed on the need to create an innovative educational environment, whose structure should cover the development strategy, the tactics of forming innovative processes, defining innovation content, ensuring its implementation, predicting results. Between 2013 and 2018, the mentioned school implemented such projects as "The Road to Professional Growth", aimed at improving teachers' skills, enhancing their motivation and professional competencies; "Following Learning Trend", aimed at promoting the use of tablets and smartphones during the educational process, verifying their efficiency and accessibility, ensuring easy learning, enhancing students' motivation; "Virtual Reality as a Path to Real Virtuality", which included introducing new forms and methods in teaching, promoting critical thinking and learner autonomy, motivating students to struggle with digital dependence and use ICT skills to gain knowledge; "Practical Steps in Environmental Education of Students", intended to change the philosophy of students' environmental thinking: to pay attention to environmental problems, enhance creative and cognitive activity, form a habit of sorting out waste and show that joint actions and even small individual contribution can change the educational institution and the country in general; "Agents of Change: from Dream to Action", aimed at realizing such areas as education for all; accessible, desirable and informative education; an open way to the international information space.

The teaching staff also designed an e-manual on the course, titled "Cooking Technology and Basics of Commodity Research".

The implementation of these projects made it possible to accumulate certain relevant information and also significantly influence the participants in the educational process in the context of developing pedagogical innovative activities and forming professional competency in students. The main project principles are as follows: focus on cooperation; developing a personality of both teachers and students; combining theory and practice; incorporating the activity-based approach in learning. While working on the projects, students and teachers have improved their creativity and teamwork skills as the subjective parts of professional competency.

It must be noted that Berezivka Vocational School of Odesa National Polytechnic University implements an authentic and historical educational project, titled "The Keepers of Ukraine" as an effective pedagogical method of forming an innovative educational environment for vocational training of workers skilled in providing services. The project aims to create an authentic, historical and ethnographic collection of costumes. The main idea of the project is related to revealing themes of Ukrainian clothes, the concept of the national costume, discovering novel views on antiquity and preservation of spiritual values. The creative group identified historical, literary, ethnographic, folklore, artistic sources, whose analysis made it possible to create a new collection dedicated to the Ukrainian woman and keeper as a special world phenomenon. The peculiarity of such collections consists in innovative project-based activities of teachers and student accorded with curricula and programmes of vocational training for workers skilled in light industry.

Educational activities of Shostka Centre for Vocational Education are aimed at creating an innovative educational environment, which differs from the traditional content, organizational structure and management system. It involves using information and communication technologies, which prepare students for a fulfilling life in the information society and contribute to forming their critical thinking when working with vast arrays of information, learner autonomy, problem-solving skills, communication skills, analytical thinking, cooperation and collaboration skills. The main areas for implementing information and communication technologies are the following:

$\checkmark \quad$ using cloud technologies: applications; electronic journals and diaries; online services for the educational process, communication and testing; systems of distance learning; media library; file storage, shared access; videoconferences; an e-mail with a domain of the education institution;

$\checkmark \quad$ applying an educational kit for designing interactive tasks with LearningApps;

$\checkmark$ employing services for creating and uploading presentations: Empress, Google Docs, Prezi, ZohoShow, SlideShare, VCASMO, Knoodle;

$\checkmark \quad$ incorporating computer tests for monitoring student knowledge with a master-test programme;

$\checkmark$ elaborating e-textbooks.

The obtained results prove that an innovative educational environment ensures the continuity of vocational education in accordance with the latest 
technologies; the openness and accessibility of education to meet the growing need of society for skilled workers; the achievement of an individual's success in the modern world and expected learning outcomes.

Conclusions. In Ukraine, vocational education teachers employ different approaches to creating an innovative educational environment. However, they all agree on the interconnection between positive results obtained from the process of forming professional competency in future workers and the conditions of its implementation. It was found that the process of creating an innovative educational environment significantly influenced the processes of forming and developing professional skills in teachers, promoting pedagogical innovations, increasing the potential of teachers. Pedagogical conditions for creating and maintaining an innovative educational environment in educational institutions were singled out. They are partnership cooperation, respect and trust of all participants in the educational process; focus on development and self-development of every individual; creative activity; effective use of scientific and methodological, material and technical capabilities and human resources of educational institutions; employment of personality-oriented innovative pedagogical technologies.

\section{List of references}

Ващенко, Л., 2012. Інноваційне середовище післядипломної педагогічної освіти. Післядипломна освіта, 1, с. $37-40$.

Верховна Рада України. Законодавство України, 2017. Про освіту. [online] (Останнє оновлення 19 Січень 2019) Доступно: <http: //zakon2.rada.gov.ua/laws/show/2145-19.> [Дата звернення 02 Травень 2019].

Каташов, А. І., 2001. Педагогічні основи розвитку інновачійного освітнього середовища сучасного ліщею: автореферат. Кандидат наук Луганський державний педагогічний університет імені Тараса Шевченка.

Кух, А. М., 2008. Освітнє середовище в структурі інноваційної системи фахової підготовки майбутніх учителів фізики. В: Предметні дидактики в контексті формування компетентністно-світоглядних професійних якостей майбутнього фахівия, [online] частина 2, с. 73-76. Доступно: <Ошибка! Недопустимый объект гиперссылки.> [Дата звернення 02 Травень 2019].

Ничкало, Н. Г., 2008. Трансформачия професійно-технічної освіти України: монографія. К.: Педагогчна думка.

Щекатунова, Г. Д., ред., Тесленко, В. В., Цимбалару А. Д. та ін., 2013. Організаиійин-педагогічні засади інновачийного розвитку загальноосвітнього навчального закладу: монографія. К.: Педагогічна думка.

Разіна, Н. О., 2009. Акмеологічний підхід до розвитку професіоналізму сучасного педагога в інноваційному освітньому середовищі середньої школи. Вісник наукової школи педагогів "AKME", [online] 3. Доступно: <http:// www.intellect-invest.org.ua/ukr/school_akme_vestnik_akme_akme_3_2009_razina_akmeolog_podhod_k_razvit/> [ Дата звернення 02 Травень 2019].

Романова, Г. М., 2014. Проектування технологій професійного навчання майбутніх кваліфікованих робітників. Професійно-технічна освіта, 1 , с. 47-64.

Шапран, О. І., 2010. Створення інноваційного освітнього середовища в процесі професійної підготовки майбутнього вчителя. Педагогіка, психологія та медико-біологічні проблеми фізичного виховання і спорту, 9, с. 108-110.

\section{Translated \& Transliterated}

Vashchenko, L., 2012. Innovatsiine seredovyshche pisliadyplomnoi pedahohichnoi osvity [Innovative environment of postgraduate education]. Pisliadyplomna osvita [Postgraduate Education], 1, s. 37-40, [in Ukrainian].

Verkhovna Rada Ukrainy. Zakonodavstvo Ukrainy [Verkhovna Rada of Ukraine. Legislation of Ukraine], 2017. Pro osvitu [On education]. [online] (Ostannie onovlennia 19 Sichen 2019) Dostupno: $<$ http: //zakon2.rada.gov.ua/laws/show/ 2145-19.> [Data zvernennia 02 Traven 2019], [in Ukrainian].

Katashov, A. I., 2001. Pedahohichni osnovy rozvytku innovatsiinoho osvitnoho seredovyshcha suchasnoho litseiu: avtoreferat [Pedagogical principles for developing an innovative educational environment in a modern lyceum]. Kandydat nauk. Luhanskyi derzhavnyi pedahohichnyi universytet imeni Tarasa Shevchenka, [in Ukrainian].

Kukh, A. M., 2008. Osvitnie seredovyshche v strukturi innovatsiinoi systemy fakhovoi pidhotovky maibutnikh uchyteliv fizyky [An educational environment within the innovative system of professional training for future physics teachers]. V: Predmetni dydaktyky v konteksti formuvannia kompetentnistno-svitohliadnykh profesiinykh yakostei maibutnoho fakhivtsia [Subject Didactics in the Context of Forming Competency-Based and Ideological Professional Qualities in a Future Specialist], [online] chastyna 2, c. 73-76. Dostupno: <www.mvf. kam-pod.org/zbirnuku/Zbirnyk14/e-book/2-07-Kuhh.pdf.> [Data zvernennia 02 Traven 2019], [in Ukrainian].

Nychkalo, N. H., 2008. Transformatsiia profesiino-tekhnichnoi osvity Ukrainy: monohrafiia [Transforming vocational education in Ukraine]. K.: Pedahohchna dumka, [in Ukrainian].

Shchekatunova, H. D., red., Teslenko, V. V., Tsymbalaru A. D. ta in., 2013. Orhanizatsiino-pedahohichni zasady innovatsiinoho rozvytku zahalnoosvitnoho navchalnoho zakladu: monohrafiia [Organizational and pedagogical principles of innovative development in comprehensive schools]. K.: Pedahohichna dumka, [in Ukrainian].

Razina, N. O., 2009. Akmeolohichnyi pidkhid do rozvytku profesionalizmu suchasnoho pedahoha v innovatsiinomu osvitnomu seredovyshchi serednoi shkoly [Acmeological approach to developing professionalism in a modern teacher 
within an innovative educational environment of middle school]. Visnyk naukovoi shkoly pedahohiv "AKME" [The Journal of the AKME Scientific School of Teachers], [online] 3. Dostupno: <http://www.intellect-invest.org.ua/ukr/ school_akme_vestnik_akme_akme_3_2009_razina_akmeolog_podhod_k_razvit/> [Data zvernennia 02 Traven 2019], [in Ukrainian].

Romanova, H. M., 2014. Proektuvannia tekhnolohii profesiinoho navchannia maibutnikh kvalifikovanykh robitnykiv [Designing technologies for vocational training of future skilled workers]. Profesiino-tekhnichna osvita [Vocational Education], 1, s. 47-64, [in Ukrainian].

Shapran, O. I., 2010. Stvorennia innovatsiinoho osvitnoho seredovyshcha v protsesi profesiinoi pidhotovky maibutnoho vchytelia [Creating an innovative educational environment during professional training of a future teacher]. Pedahohika, psykholohiia ta medyko-biolohichni problemy fizychnoho vykhovannia i sportu [Pedagogy, Psychology, Medical and Biological Problems of Physical Education and Sport], 9, s. 108-110, [in Ukrainian].

УДК 377.3:005.336.2-027.561]:005.34

\section{Інноваційне освітне середовище формування професійної компетентності майбутніх кваліфікованих робітників}

\section{Тетяна Пятничук,}

кандидат педагогічних наук, заступник начальника відділу наукового та навчально-методичного забезпечення змісту професійної освіти, ДНУ "Інститут модернізації змісту освіти"

Реферат. У статті здійснено аналіз суті поняття "інноваційне освітнє середовище", визначено його зміст для закладів професійної (професійно-технічної) освіти (далі: ЗП(ПТ)О). Висвітлено досвід роботи педагогічних колективів закладів освіти зі створення інноваційного освітнього середовища та формування професійної компетентності майбутніх робітників. Охарактеризовано основні підходи до створення інноваційного освітнього середовища ЗП(ПТ)О для професійної підготовки майбутніх кваліфікованих робітників: гуманістичного (людиноцентризм, гармонізація відносин, формування духовної культури); системного (вдосконалення освітнього середовища як цілісної розвиваючої системи); інформаційного (достатній рівень інформаційної культури); інноваційного (творча взаємодія, формування готовності до майбутньої професійної діяльності).

На основі практичного досвіду закладів професійної освіти України виокремлено педагогічні умови створення та функціонування інформаційного освітнього середовища закладу освіти: партнерське співробітництво, повага та довіра всіх учасників освітнього процесу; спрямування на розвиток і саморозвиток кожної особистості; робота в творчому пошуковому режимі; ефективне використання науково-методичних, матеріально-технічних та кадрових можливостей закладів освіти; застосування особистісно орієнтованих інноваційних педагогічних технологій.

Акцентовано увагу на важливості використання педагогами особистісно орієнтованих педагогічних технологій. Показано, що педагогічні колективи ЗП(ПТ)О мають різне бачення підходів до створення інноваційного освітнього середовища. Водночас усі погоджуються з тим, що створення інноваційного освітнього середовища має значний позитивний вплив на формування та розвиток професійної майстерності педагогів, розвиток педагогічної інноваційної діяльності, зміцнення педагогічного колективу.

Ключові слова: інноваційне освітнє середовище, професійна компетентність, готовність педагогів до інновачійної діяльності, експериментальна робота.

Received: 06 May 2019

Accepted: 24 May 2019 